\title{
Minat Memesan Kembali Transportasi Online
}

\author{
Sukma Irdiana ${ }^{1}$, Jovi Iristian $^{2}$ \\ STIE Widya Gama Lumajang ${ }^{1}$ \\ Fakultas Ekonomi dan Bisnis, Universitas DR. Soetomo ${ }^{2}$ \\ Email: sukmapasah@gmail.com
}

https://doi.org/10.30741/wiga.v9i2.448

INFO ARTIKEL

Tanggal masuk:

15 Agustus 2019

Tanggal Revisi :

19 September 2019

Tanggal Diterima :

30 September 2019

\section{A B S T R A K}

Jasa transportasi telah mengalami perkembangan yang sangat pesat, saat ini transportasi umum sudah dapat diakses melalui internet. Perkembangan ini memudahkan masyarakat dalam memanfaatkan pelayanan jasa transportasi umum. Masyarakat kini dapat menggunakan jasa transportasi umum dimana dan kapan pun mereka inginkan. Kini masyarakat yang tinggal di Daerah Perkotaan sudah mulai beralih menggunakan jasa transportasi umum. Jasa transportasi online adalah industri yang populer sekarang ini. Tujuan dari penelitian ini adalah untuk mengetahui kualitas pelayanan dan harga terhadap minat memesan kembali jasa transportasi online dengan kepuasan pelaggan sebagai variable intervening. Populasi adalah pelanggan pengguna jasa transportasi online "Grab". Penelitian ini menggunakan 100 sampel responden dengan kriteria telah menggunakan layanan jasa transportasi online lebih dari dua kali. Kemudian data dianalisis menggunakan analisis jalur. Berdasarkan hasil penelitian, hasil bahwa kualitas layanan berpengaruh positif dan signifikan terhadap kepuasan pelanggan, sedangkan harga tidak berpengaruh negatif dan signifikan terhadap kepuasan pelanggan. Namun kualitas layanan dan harga berpengaruh positif dan signifikan terhadap minat memesan kembali dengan kepuasan pelanggan sebagai variable mediasi.

Kata kunci: Kualitas Pelayanan, Harga, Kepuasan Pelanggan, Minat Menggunakan Kembali Jasa Transportasi Online.

\begin{abstract}
A B S T R A C T
Transportation services have experienced very rapid development, currently public transportation can be accessed via the internet. This development makes it easier for the public to take advantage of public transportation services. People can now use public transportation services where and whenever they want. Now people who live in urban areas have started to switch to using public transportation services. Online transportation services are a popular industry today. The purpose of this study was to determine the quality of service and the price of interest in re-ordering online transportation services with customer satisfaction as an intervening variable. The population is customers of online transportation service users "Grab". This study uses 100 sample respondents with the criteria of using online transportation services more than twice. Then the data are analyzed using path analysis. Based on the results of the study, the results that service quality has a positive and significant effect on customer satisfaction, while price does not have a negative and significant effect on customer satisfaction. But partially the quality of service and price have a positive and significant effect on the interest of reordering with customer satisfaction as a mediating variable.
\end{abstract}


Keywords: Service Quality, Price, Customer Satisfaction, Interest in Reusing Online Transportation Services.

\section{PENDAHULUAN}

Transportasi adalah pemindahan barang dan manusia dari tempat asal ke tempat tujuan. Sehingga dengan kegiatan tersebut maka terdapat tiga hal yaitu adanya muatan yang diangkut, tersedianya kendaraan sebagai alat angkut, dan terdapatnya jalan yang dapat dilalui. Menurut Tamin (1999), prasarana transportasi mempunyai dua peran utama, yaitu: Sebagai alat bantu untuk mengarahkan pembangunan di daerah perkotaan; dan sebagai prasarana bagi pergerakan manusia dan/atau barang yang timbul akibat adanya kegiatan di daerah perkotaan tersebut dan, untuk mendukung pergerakan manusia dan barang. Di Indonesia ada beberapa alat transportasi yang digunakan, transportasi darat, laut dan udara. Sejauh ini yang ada di negara kita baru itu saja. Melihat begitu pentingnya peran transportasi dalam kehidupan sehari-hari muncullah transportasi berbasis online. Jasa transportasi online merupakan jasa transportasi yang memanfaatkan kemajuan teknologi. Teknologi diciptakan tujuannya untuk mempermudah segala aktivitas-aktivitas manusia yang dilakukan sehari-hari. Transportasi berbasis online diciptakan dengan tujuan untuk mempermudah seseorang yang ingin bepergian. Sebagai contoh: mudah memesannya, efesien dan efektif. Ini merupakan sebuah terobosan baru yang patut diberi apresiasi.

Jasa transportasi telah mengalami perkembangan yang sangat pesat, saat ini transportasi umum sudah dapat diakses melalui internet. Perkembangan ini memudahkan masyarakat dalam memanfaatkan pelayanan jasa transportasi umum. Masyarakat kini dapat menggunakan jasa transportasi umum dimana dan kapan pun mereka inginkan. Kini masyarakat yang tinggal di Daerah Perkotaan sudah mulai beralih menggunakan jasa transportasi umum. Jasa transportasi online adalah industri yang populer sekarang ini. Keberadaan transportasi online membuat orang yang ingin memesan dan menggunakan jasa transportasi umum seperti ojek dan taksi tidak perlu lagi pergi ke pangkalan ojek atau terminal, cukup hanya melalui aplikasi di smartphone. Cara pemesanan ini sangat disukai karena lebih mudah dan praktis. Saat ini ada banyak pilihan jasa transportasi online di Indonesia seperti Gojek, Grab, dan Uber (Adnyana \& Suprapti, 2018). Persaingan pada industri jasa transportasi online mengharuskan perusahaan berlomba-lomba untuk memberikan kualitas pelayanan yang terbaik untuk menjaga kepuasan dari pelanggan (Farida dkk., 2016). Kualitas pelayanan adalah faktor yang menentukan keberhasilan dimana kemampuan perusahaan dalam memberikan kualitas pelayanan yang berkualitas kepada konsumen dan sebagai strategi perusahaan untuk mempertahaan diri dan mencapai kesuksesan dalam menghadapi persaingan (Lupiyoadi, 2013).

Kualitas pelayanan dikatakan memuaskan jika layanan yang dirasakan sama atau melebihi kualitas pelayanan yang diharapkan. Pelayanan yang seperti inilah yang dipersepsikan sebagai pelayanan berkualitas dan memuaskan. Harapan konsumen tersebut tercermin pada pelayanan yang baik, ramah tamah, sopan santun, ketepatan waktu, dan kecepatan menjadi nilai penting yang diharapkan oleh para konsumen. Kosumen yang merasa puas secara tidak langsung akan mendorong terjadinya rekomendasi dari mulut ke mulut, bahkan dapat memperbaiki citra perusahaan di mata konsumen. Oleh karena itu, kualitas pelayanan harus menjadi fokus utama perhatian perusahaan karena dapat menciptakan kepuasan pelanggan (Zahra, 2017). Harga adalah sejumlah uang yang dibutuhkan untuk mendapatkan suatu barang atau jasa (Stanton, 2007). Harga adalah variabel penting dalam sebuah pemasaran, dimana harga dapat mempengaruhi pengambilan keputusan kosumen untuk membeli suatu barang atau jasa (Tjiptono, 2008). Bagi pelanggan yang sensitif terhadap harga, maka akan mempersepsikan harga adalah sumber kepuasan yang penting karena mereka akan memperoleh value of money yang tinggi (Irawan, 2002).

Kepuasan pelanggan merupakan hasil dari perbandingan antara harapan dan kenyataan yang diterima pelanggan setelah mengkonsumsi barang atau jasa. Apabila pelanggan transportasi online 
merasa puas saat menggunakan jasa layanan transportasi online maka akan timbul kepercayaan dan loyalitas pelanggan untuk kembali menggunakan jasa layanan transportasi online tersebut. Konsep kepuasan pelanggan merupakan hal penting bagi para manajer pemasaran dimana kepuasan pelanggan dapat mendorong pembelian ulang (Fornell, 1992). Dari 2 jasa transportasi populer di Indonesia, Grab menempati urutan kedua berdasarkan pada tingkat kepuasan pelanggan. Ada banyak faktor yang mempengaruhi minat seseorang untuk berbelanja di situs online, seperti kepuasan pelanggan, kepercayaan, loyalitas pelanggan serta faktor lainnya yang pada akhirnya akan menimbulkan minat pada pelanggan untuk membeli produk itu atau tidak. Minat beli adalah tahap kecenderungan pelanggan untuk bertindak sebelum keputusan pembelian benar-benar dilaksanakan (Kinnear \& Taylor, 1995). Beberapa faktor yang mempengaruhi minat seseorang untuk berbelanja di situs online diantaranya kepercayaan, kemudahan transaksi, hemat waktu dan tenaga, harga, kualitas produk dan pelayanan, kepuasan pelanggan serta beberapa faktor lainnya dapat mendorong minat pada pelanggan untuk membeli produk itu atau tidak. Kepuasan yang pelanggan rasakan atas kualitas produk maupun kualitas pelayanan dapat mendorong kepercayaan pelanggan untuk melakukan pembelian kembali pada jasa transportasi online seperti Grab. Selain itu, kepuasan pelanggan juga dapat mendorong adanya kepercayaan dan loyalitas pelanggan. Jika pelanggan merasa percaya dan loyal terhadap suatu jasa transportasi online maka pelanggan tidak akan merasa ragu untuk berbelanja di jasa transportasi online tersebut. Sebaliknya jika pelanggan merasa kurang puas maka pelanggan akan merasa ragu bahkan tidak percaya pada jasa transportasi online tersebut dan pelanggan tidak akan loyal dengan jasa transportasi online tersebut dan lebih memilih beralih ke jasa transportasi online lainnya (Norhermaya, 2016).

Berdasarkan data yang diperoleh dari majalah Tempo (2017), peringkat jasa transportasi online Go-Jek, Grab dipilih 66,9 persen responden. Sedangkan Uber digunakan 51 persen dan My Bluebird 4,4 persen. Alasan responden memilih atau menggunakan transportasi online, kata Tulus, pada umumnya menyatakan karena murah $(84,1$ persen), cepat $(81,9$ persen), nyaman $(78,8$ persen), dan aman (61,4 persen). Adapun untuk moda transportasi yang dipilih konsumen, 55 persen menggunakan transportasi online jenis mobil dan motor. Sedangkan yang menggunakan motor saja 21 persen dan mobil saja 24 persen. Terkait dengan pelayanan, hasil survei menunjukkan konsumen secara dominan menjawab sangat baik 77,7 persen. Namun, ketika ditanya apakah konsumen pernah dikecewakan terkait dengan pelayanannya, 41 persen responden mengaku pernah mengalaminya. Adapun kasus yang paling sering terjadi adalah 22,3 persen responden pernah dikecewakan karena pengemudi minta dibatalkan. Disusul sulitnya mendapatkan pengemudi 21,19 persen. Dari data yang ada masih terlihat kurangnya kualitas pelayanan, harga, kepuasan pelanggan dengan minat memesan kembali jasa transportasi online. Berdasarkan uraian dan data yang ada, timbul keinginan penulis untuk meneliti kualitas pelayanan, harga, kepuasan pelanggan dan minat memesan kembali jasa transportasi online pada "Grab" (Iristian, 2019).

\section{METODE PENELITIAN}

Penelitian ini tergolong penelitian asosiatif, yaitu penelitian yang bertujuan untuk mengetahui hubungan dua variable atau lebih. Grab di Surabaya dipilih sebagai lokasi penelitian karena Surabaya merupakan pusat pendidikan dan perdagangan. Populasi dalam penelitian ini adalah seluruh pengguna Grab di Surabaya. Penentuan sampel menggunakan metode non probability sampling dengan teknik purposive sampling dengan kriteria sampel yaitu pelanggan yang telah penggunakan Grab minimal dua kali dalam seminggu. Metode pengumpulan data yang digunakan adalah survey yaitu dengan menggunakan kuesioner sebagai intsrumen penelitian. Penyebaran kuesioner menggunakan dua cara yaitu secara langsung dan online menggunakan Google form. Data yang telah terkumpul nantinya akan ditabulasi untuk dianalisis menggunakan teknik statistik deskritif dan teknik statistik inferensial. Analisis deskriptif bertujuan untuk mengetahui karakteristik dan tanggapan responden mengenai item-item pernyataan dalam kuesioner, sedangkan statistik inferensial untuk menguji kebenaran hipotesis-hipotesis yang telah dirumuskan dengan menggunakan teknik analisis jalur. 


\section{HASIL DAN PEMBAHASAN}

Deskripsi responden dalam penelitian ini adalah sebagai berikut :

Tabel 1. Deskripsi Responden

\begin{tabular}{|c|c|c|c|}
\hline No & Karakteristik Responden & Katagori & Frekuensi \\
\hline \multirow[t]{5}{*}{1} & Umur & $<20$ Tahun & 9 \\
\hline & & 21-30 Tahun & 46 \\
\hline & & 31-40 Tahun & 23 \\
\hline & & 41-50 Tahun & 12 \\
\hline & & $>50$ Tahun & 10 \\
\hline \multirow[t]{2}{*}{3} & Jenis Kelamin & Laki-Laki & 36 \\
\hline & & Perempuan & 64 \\
\hline \multirow[t]{4}{*}{4} & Pendidikan & SMA & 22 \\
\hline & & S1 & 57 \\
\hline & & $\mathrm{S} 2$ & 19 \\
\hline & & S3 & 2 \\
\hline \multirow[t]{4}{*}{5} & Pekerjaan & PNS/BUMN & 21 \\
\hline & & Swasta & 35 \\
\hline & & Mahasiswa & 23 \\
\hline & & Ibu Rumah Tangga & 21 \\
\hline \multirow[t]{4}{*}{6} & Penghasilan & $<2$ Juta & 31 \\
\hline & & 2-10 Juta & 67 \\
\hline & & 11-20 Juta & 2 \\
\hline & & $>21$ Juta & 0 \\
\hline
\end{tabular}

Sumber : Olahan data (2019)

Uji instrumen terdiri atas uji validitas dan rentabilitas. Dalam uji validitas semua hasil uji berada diatas tingkat korelasi yaitu 0,3. Hal ini dikarenakan syarat minimum untuk dianggap suatu butir instrument valid adalah nilai indeks valid adalah nilai indeks validitasnya $\geq 0,3$ (Sugiyono, 2016). Sedangkan uji reliabilitas, hasil uji berada diatas 0,6, yang mana untuk melihat andal tidaknya suatu alat ukur digunakan pendekatan secara statistika, yaitu melalui koefisien reliabilitas dan apabila koefisien reliabilitasnya lebih besar dari 0.60 maka secara keseluruhan pernyataan tersebut dinyatakan andal (reliabel).

Uji asumsi klasik terdiri atas uji normalitas, uji multikolinearitas, dan uji heteroskedastisitas. Dalam uji normalitas, hasil menunjukkan bahwa titik-titik menyebar mengikuti garis diagonal, hal ini menunjukan model yang diuji berdistribusi normal. Ini sesuai dengan uji normalitas, diuji menggunakan probability plots untuk melihat apakah berdistribusi normal atau tidak (Ghozali, 2011). Uji linieritas, hasil menunjukkan bahwa semua variable memiliki nilai signifikansi yang lebih besar dari 0,05 (Sig>0,05), hal ini menunjukkan bahwa semua variable penelitian adalah linier. Uji multikolinearitas, hasil dalam uji ini menunjukkan bahwa VIF nya dibawah 10 . Hal ini sesuai dengan suatu model dikatakan tidak terjadi multikolinearitas apabila nilai tolerance $\geq 0,1$ dan VIF $\leq 10$ (Ghozali, 2011). Uji heteroskedastisitas, dalam uji ini hasil menunjukkan penyebaran titik kesegala arah tanpa membuat pola tertentu sehingga dapat disimpulkan bahwa tidak terjadi heteroskesdastisitas atau homoskesdatisitas.

Uji statistik yang digunakan dalam penelitian ini adalah uji t, koefesien determinasi dan uji F. Berikut hasil uji statistic :

Tabel 2. Uji Goodness Of Fit Model 1

\begin{tabular}{llll}
\hline Model & B & Std. Error & Beta \\
\hline
\end{tabular}




\begin{tabular}{lccc}
\hline (Constant) & 7,957 & 0,862 & \\
JML Kualitas & 0,316 & 0,058 & 0,621 \\
Pelanggan & & & \\
JML Harga & $-0,084$ & 0,055 & $-0,174$ \\
\hline
\end{tabular}

Sumber : Olahan Data SPSS 21 (2019)

Model regresi linier berganda pada penelitian ini adalah :

$\mathrm{Y}=7,957+0,316 \mathrm{X} 1-0,084 \mathrm{X} 2$

Tabel 3. Uji Goodness Of Fit Model 2

\begin{tabular}{lllll}
\hline \multicolumn{1}{c}{ Model } & \multicolumn{1}{c}{ B } & Std. Error & Beta \\
\hline (Constant) & 7,120 & 2,294 & \\
JML Kualitas & 0,132 & 0,127 & 0,137 \\
$\begin{array}{l}\text { Pelanggan } \\
\text { JML Harga }\end{array}$ & 0,348 & 0,107 & 0,376 \\
JML Kepuasan & 0,146 & 0,197 & 0,077 \\
Pelanggan & & & \\
\hline
\end{tabular}

Sumber : Olahan Data SPSS 21 (2019)

Model regresi linier sederhana pada penelitian ini adalah :

$\mathrm{Y} 2=7,129+0,132 \mathrm{X} 1+0,348 \mathrm{X} 2+0,146 \mathrm{Y} 1$

Tabel 4. Koefisien Determinasi $\left(R^{2}\right)$ Model 1

\begin{tabular}{lllll}
\hline Model & R & R Square & $\begin{array}{c}\text { Adjusted R } \\
\text { Square }\end{array}$ & $\begin{array}{c}\text { Std. Error of the } \\
\text { Estimate }\end{array}$ \\
\hline 1 &, $525^{\mathrm{a}}$ &, 276 &, 261 & 1,29254 \\
\hline Sumber : Olahan Data SPSS $21(2019)$ & &
\end{tabular}

Berdasarkan table 4, koefisien korelasi (R) sebesar 0.525 menunjukkan bahwa keeratan hubungan antara variabel bebas kualitas pelayanan (X1) dan harga (X2) terhadap Kepuasan Pelanggan (Y) adalah kuat. Koefisien Determinasi $\left(R^{2}\right)$ sebesar 0.276 memiliki arti bahwa besarnya proporsi kemampuan variabel bebas yaitu kualitas pelayanan (X1) dan harga (X2) menjelaskan variabel terikat Kepuasan Pelanggan pelanggan (Y) adalah sebesar 27,6\%, sedangkan sisanya yaitu 72,4\% dipengaruhi oleh variabel lain di luar variabel bebas yang digunakan dalam penelitian ini.

\begin{tabular}{lllll}
\multicolumn{4}{c}{ Tabel 5. Koefisien Determinasi $\left(\boldsymbol{R}^{2}\right)$ Model 2 } \\
\hline Model & $\mathbf{R}$ & R Square & $\begin{array}{c}\text { Adjusted R } \\
\text { Square }\end{array}$ & $\begin{array}{c}\text { Std. Error of the } \\
\text { Estimate }\end{array}$ \\
\hline 1 & \multicolumn{5}{l}{, $506^{\mathrm{a}}$} &, 256 &, 233 & 2,50899 \\
\hline Sumber : Olahan Data SPSS $21(2019)$
\end{tabular}

Berdasarkan table 5, koefisien korelasi (R) sebesar 0.506 menunjukkan bahwa keeratan hubungan antara variabel bebas kepuasan pelanggan (Y1) terhadap minat membeli ulang (Y2) adalah kurang kuat. Koefisien Determinasi $\left(R^{2}\right)$ sebesar 0.256 memiliki arti bahwa besarnya proporsi kemampuan variabel bebas yaitu kepuasan pelanggan (Y1) menjelaskan variabel terikat minat membeli ulang (Y2) adalah sebesar 25,6\%, sedangkan sisanya yaitu 74,4\% dipengaruhi oleh variabel lain di luar variabel bebas yang digunakan dalam penelitian ini.

Tabel 6. Uji F Model 1

\begin{tabular}{lllllll}
\hline Model & Sum of Squares & Df & Mean Square & F & Sig. \\
\hline
\end{tabular}




\begin{tabular}{llllll}
\hline Regression & 61,785 & 2 & 30,892 & 18,491 &, $000^{\mathrm{b}}$ \\
Residual & 162,055 & 97 & 1,671 & & \\
Total & 223,840 & 99 & & & \\
\hline
\end{tabular}

Sumber : Olahan Data SPSS 21 (2019)

Berdasarkan nilai statistik pada tabel 6, dapat diketahui bahwa nilai F hitung adalah sebesar 18.491 serta nilai signifikansi uji $\mathrm{F}$ yang nilainya kurang dari $0.05(\mathrm{a}=5 \%)$. Dari hasil ini dapat disimpulkan bahwa variabel bebas kualitas pelayanan (X1) dan harga (X1) secara bersama-sama (simultan) berpengaruh signifikan terhadap variabel terikat yaitu kepuasan pelanggan (Y).

Tabel 7. Uji F Model 2

\begin{tabular}{llllllc}
\hline \multicolumn{1}{c}{ Model } & \multicolumn{1}{c}{ Sum of Squares } & Df & \multicolumn{1}{c}{ Mean Square } & F & Sig. \\
\hline Regression & 207,679 & 3 & 69,226 & 10,997 &, $000^{\mathrm{b}}$ \\
Residual & 604,321 & 96 & 6,295 & & \\
Total & 812,000 & 99 & & & \\
\hline
\end{tabular}

Sumber : Olahan Data SPSS 21 (2019)

Berdasarkan nilai statistik pada tabel 7, dapat diketahui bahwa nilai F hitung adalah sebesar 10.997 serta nilai signifikansi uji $\mathrm{F}$ yang nilainya kurang dari $0.05(\mathrm{a}=5 \%)$. Dari hasil ini dapat disimpulkan bahwa variabel bebas kualitas pelayanan (X1) dan harga (X1) serta kepuasan pelanggan (Y1) secara bersama-sama (simultan) berpengaruh signifikan terhadap variabel terikat yaitu minat memesan kembali (Y2).

Tabel 8. Uji t Model 1

\begin{tabular}{lccl}
\hline \multicolumn{1}{c}{ Model } & \multicolumn{1}{c}{ t } & Sig & \multicolumn{1}{c}{ Keterangan } \\
\hline (Constant) & 9,229 & 0,000 & \\
JML Kualitas Pelanggan & 5,481 & 0,000 & Signifikan \\
JML Harga & 1,534 & 0,128 & Tidak Signifikan \\
\hline
\end{tabular}

Sumber : Olahan Data SPSS 21 (2019)

Berdasarkan table 8 menunjukkan bahwa variabel bebas kualitas pelayanan (X1) menghasilkan nilai signifikansi t hitung yang lebih kecil dari $0.05(\alpha=5 \%)$ yaitu 0.000 . Dari hasil ini ini maka dapat disimpulkan bahwa secara parsial variabel tersebut yaitu kualitas pelayanan (X1) memiliki pengaruh yang signifikan terhadap kepuasan pelanggan atau dengan kata lain apabila semakin baik, maka kepuasan pelanggan akan mengalami peningkatan secara nyata. Dari hasil ini hipotesis pertama penelitian dapat diterima kebenarannya. Sedangkan variabel bebas harga (X2) menghasilkan nilai signifikansi t hitung yang lebih besar dari $0.05(\alpha=5 \%)$ yaitu 0.128 . Dari hasil ini ini maka dapat disimpulkan bahwa secara parsial variabel tersebut yaitu harga (X2) tidak memiliki pengaruh yang signifikan terhadap kepuasan pelanggan atau dengan kata lain apabila semakin baik, maka harga akan mengalami penurunan secara nyata. Dari hasil ini hipotesis kedua penelitian dapat diterima kebenarannya.

Tabel 9. Uji t Model 2

\begin{tabular}{lcll}
\hline \multicolumn{1}{c}{ Model } & \multicolumn{1}{c}{ T } & \multicolumn{1}{c}{ Sig } & Keterangan \\
\hline (Constant) & 3,104 & 0,003 & \\
JML Kualitas Pelanggan & 1,034 & 0,304 & Tidak \\
& & & Signifikan \\
JML Harga & 3,216 & 0,002 & Signifikan \\
JML Kualitas Pelanggan & 0,743 & 0,460 & Tidak \\
& & & Signifikan \\
\hline
\end{tabular}

Sumber : Olahan Data SPSS 21 (2019)

Berdasarkan table 9 menunjukkan bahwa variabel bebas kualitas pelayanan (X1) menghasilkan nilai signifikansi t hitung yang lebih besar dari $0.05(\alpha=5 \%)$ yaitu 0.304 . Dari hasil ini ini maka 
dapat disimpulkan bahwa secara parsial variabel tersebut yaitu kualitas pelayanan (X1) memiliki pengaruh yang tidak signifikan terhadap minat memesan kembali atau dengan kata lain apabila semakin buruk kualitas pelayanan, maka minat memesan kembali konsumen akan mengalami penurunan secara nyata. Dari hasil ini hipotesis ketiga penelitian tidak dapat diterima kebenarannya. Variabel bebas harga (X2) menghasilkan nilai signifikansi t hitung yang lebih kecil dari $0.05(\alpha=5 \%)$ yaitu 0.003 . Dari hasil ini ini maka dapat disimpulkan bahwa secara parsial variabel tersebut yaitu harga (X2) memiliki pengaruh yang signifikan terhadap minat memesan kembali atau dengan kata lain apabila semakin baik, maka harga akan mengalami peningkatan secara nyata. Dari hasil ini hipotesis keempat penelitian dapat diterima kebenarannya. Sedangkan variabel bebas kepuasan pelanggan (Y1) menghasilkan nilai signifikansi t hitung yang lebih besar dari $0.05(\alpha=5 \%)$ yaitu 0.460 . Dari hasil ini ini maka dapat disimpulkan bahwa secara parsial variabel tersebut yaitu kepuasan pelanggan (Y1) memiliki pengaruh yang tidak signifikan terhadap minat memesan kembali atau dengan kata lain apabila semakin buruk kepuasan pelanggan, maka minat memesan kembali konsumen akan mengalami penurunan secara nyata. Dari hasil ini hipotesis kelima penelitian tidak dapat diterima kebenarannya.

Secara keseluruhan pengaruh persamaan substruktural 1 dan substruktural 2 dapat dilihat pada gambar 1 di bawah ini.

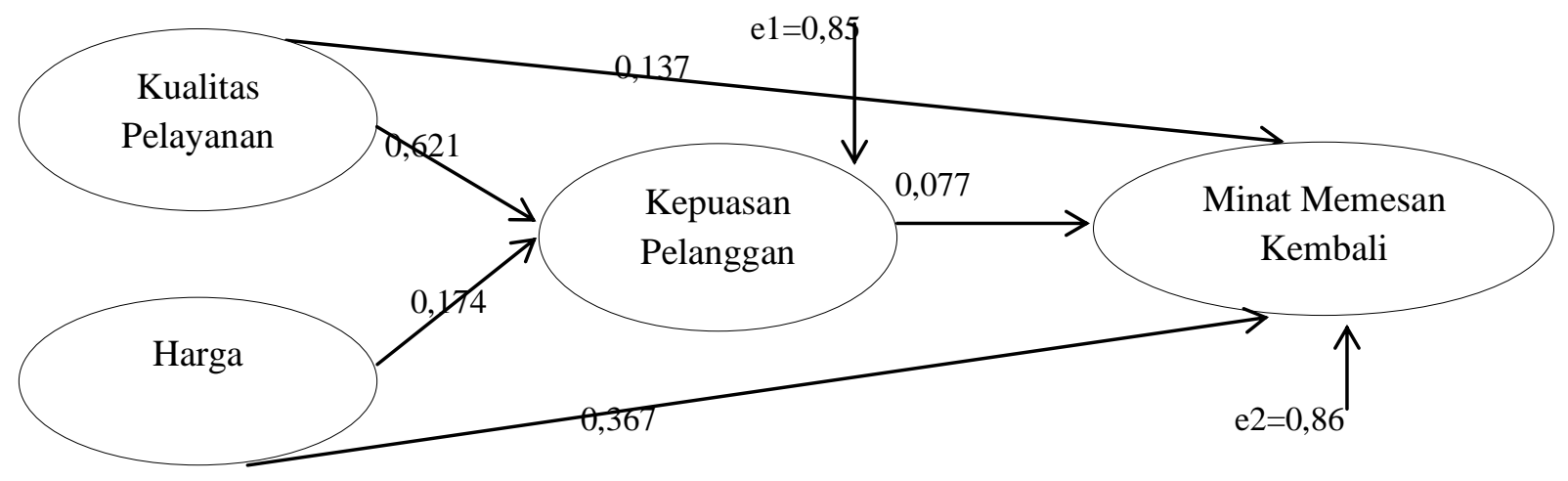

Gambar 1. Analisis Jalur

Sumber : Olahan Data SPSS 21 (2019)

Table 10. Analisis Jalur

\begin{tabular}{|c|c|c|c|}
\hline Model & $\begin{array}{l}\text { Pengaruh } \\
\text { Langsung }\end{array}$ & $\begin{array}{l}\text { Pengaruh Tidak } \\
\text { Langsung }\end{array}$ & Pengaruh Total \\
\hline \multicolumn{4}{|c|}{ Sub struktural 1 (X1 dan X2 terhadap Y1) } \\
\hline $\begin{array}{l}\text { Kualitas Pelayanan } \\
\text { (X1) }\end{array}$ & 0,621 & & 0,621 \\
\hline Harga (X2) & 0,174 & & 0,174 \\
\hline \multicolumn{4}{|c|}{ Sub struktural 2 (X1,X2, Y1 terhadap Y2) } \\
\hline $\begin{array}{l}\text { Kualitas Pelayanan } \\
\text { (X1) }\end{array}$ & & 0,048 & 0,185 \\
\hline Harga (X2) & 0,367 & 0,013 & 0,380 \\
\hline $\begin{array}{l}\text { Kepuasan Pelanggan } \\
\text { (Y1) }\end{array}$ & 0,077 & & 0,077 \\
\hline
\end{tabular}

Sumber : Olahan Data SPSS 21 (2019)

Pengaruh tidak langsung X1 terhadap Y2 melalui Y1 sebesar 0.048 dan pengaruh total sebesar 0.185 , hasil ini menunjukkan bahwa secara tidak langsung X2 terhadap Y2 mempunyai pengaruh signifikan terhadap Y1. Pengaruh tidak langsung X2 terhadap Y2 melalui Y1 sebesar 0.013 dan 
pengaruh total sebesar 0.380 , hasil ini menunjukkan bahwa secara tidak langsung X2 terhadap Y2 mempunyai pengaruh signifikan terhadap Y1.

Hasil penelitian yang menyatakan adanya pengaruh kualitas pelayanan terhadap kepuasan pelanggan, hal ini sesuai dengan teori yang dikemukakan Kotler (2002) yaitu terdapat hubungan yang erat antara kualitas pelayanan, kepuasan pelanggan, dan profitabilitas perusahaan. Semakin tinggi tingkat kualitas pelayanan menyebabkan semakin tingginya kepuasan pelanggan dan juga mendukung harga yang lebih tinggi serta biaya yang lebih rendah. Oleh sebab itu, kualitas pelayanan yang diberikan oleh jasa transportasi online "Grab" biasanya juga meningkatkan profitabilitas. Tidak jauh berbeda dengan pendapat tersebut, Zeithaml dan Bitner (1996) dalam Hamdani and Lupiyoadi (2009) dengan jelas mengemukakan bahwa faktor utama penentu kepuasan pelanggan adalah persepsi pelanggan terhadap kualitas pelayanan.

Hasil penelitian menunjukkan bahwa variabel harga tidak berpengaruh signifikan terhadap kepuasan pelanggan dengan arah hubungan negatif. Artinya pada saat harga yang dihasilkan menurun, kepuasan pelanggan semakin menurun. Hal ini dikarenakan pada saat pelanggan melakukan pemesanan jasa transportasi online cenderung melihat harga yang murah walapun kualitas pelayanan tidak menjamin. Hal ini berdampak pada penurunan kepuasan pelanggan. Hasil penelitian yang menyatakan ada pengaruh kualitas pelayanan dan harga terhadap kepuasan pelanggan secara simultan sesuai dengan hasil penelitian yang dilakukan Lubis and Martin. (2009) dimana kualitas pelayanan dan harga mempengaruhi kepuasan pelanggan secara simultan.

Hasil penelitian menunjukkan bahwa variabel kepuasan pelanggan berpengaruh signifikan terhadap minat pembelian ulang dengan arah hubungan positif. Hal ini menunjukkan bahwa kepuasan pelanggan akan terus diikuti dengan adanya pemesanan ulang jasa transportasi oleh pelanggan. Kepuasan yang dirasakan akan menunujukkan adanya pemesanan ulang pada waktu di masa mendatang dan akan memberikan rekomendasi terhadap orang lain. Respon positif yang di tunjukkan oleh pelanggan dalam hal ini adanya pemesanan kembali atau melakukan konsumsi kembali dengan produk jasa yang sama. Hal ini didukung hasil penelitian dari (Tetanoe and Dharmayanti (2014) bahwa besarnya tingkat kepuasan pelanggan akan berdampak pada meningkatnya perasaan loyal oleh pelanggan dan berakibat pelanggan akan kembali ke memesan pada jasa transportasi yang sama untuk melakukan pembelian ulang.

\section{KESIMPULAN}

Hipotesis yang diajukan dalam penelitian ini sebanyak tiga hipotesis. Simpulan dari tiga hipotesis tersebut adalah: (1) Kualitas pelayanan berpengaruh signifikan terhadap kepuasan pelanggan pengguna jasa transportasi online "Grab". Hal ini memiliki makna bahwa kualitas pelayanan yang baik dapat meningkatkan pelanggan pengguna jasa transportasi online "Grab" di Surabaya. (2) Harga tidak berpengaruh signifikan terhadap kepuasan pelanggan pengguna jasa transportasi online "Grab". Hal ini memiliki makna bahwa harga yang dirasakan cocok oleh konsumen dapat meningkatkan kepuasan pelanggan pengguna jasa transportasi online "Grab" di Surabaya. (3) Kepuasan pelanggan berpengaruh signifikan terhadap minat membeli ulang pengguna jasa transportasi online "Grab". Hal ini memiliki makna bahwa kepuasan pelanggan yang baik dapat meningkatkan pelanggan pengguna jasa transportasi online "Grab" di Surabaya. Keterbatasan Penelitian : Ruang lingkup penelitian cukup sempit hanya berdasarkan jawaban responden pengguna jasa transportasi online "Grab" di daerah Surabaya dan sekitarnya yang sudah pernah melakukan pemesanan jasa transportasi online pada Grab. Selain variabel bebas yang masuk dalam penelitian ini masih banyak faktor lain yang bisa menjadi pertimbangan untuk penelitian lanjutan. Keterbatasan waktu penelitan yang hanya dilakukan dalam waktu 1 bulan saja. 


\section{DAFTAR PUSTAKA}

Adnyana, D. G. A., \& Suprapti, N. W. S. (2018). Pengaruh Kualitas Pelayanan Dan Persepsi Harga Terhadap Kepuasan Dan Loyalitas Pelanggan Gojek Di Kota Denpasar. E-Jurnal Manajemen Unud, 7(11), $6041 \quad-\quad 6069 . \quad$ Doi: Https://Doi.Org/10.24843/Ejmunud.2018.V7.I11.P9

Alam, B. (2011). Manajemen Pemasaran Dan Pemasaran Jasa (Sembilan Ed.). Bandung: Alfabeth.

Fornell, C. (1992). A National Customer Satisfaction Barometer: The Swedish Experience. Journal Of Marketing, 56(1), 6-21.

Ghozali, I. (2011). Aplikasi Analisis Multivariate Dengan Program Spss. Semarang: Badan Penerbit Universitas Diponegoro.

Hamdani, A., \& Lupiyoadi, R. (2009). Manajemen Pemasaran Jasa. Jakarta: Salemba Empat.

Irawan, H. (2002). 10 Prinsip Kepuasan Pelanggan. Jakarta: Elex Media Komputindo.

Iristian, J. (2019). Minat Memesan Kembali Jasa Trasportasi Online. Jurnal Advantage, 3(1),

Kartajaya, H. (2002). Hermawan Kartajaya On Marketing. Jakarta: Pt. Gramedia Pustaka Utama.

Kinnear, T. C., \& Taylor, J. R. (1995). Marketing Research: An Applied Approach: Mcgraw Hill Text.

Kotler, P. (2002). Manajemen Pemasaran (Millenium Ed.). Jakarta: Pt Prenhallindo.

Kotler, P., \& Amstrong, G. (2012). Prinsip-Prinsip Manajemen (12 Ed.). Jakarta: Erlangga.

Lubis, A. N., \& Martin. (2009). Pengaruh Harga (Price) Dan Kualitas Pelayanan (Service Quality) Terhadap Kepuasan Pasien Rawat Inap Di Rsu Deli Medan. Manajemen Bisnis, 2(1), 2124.

Lupiyoadi, R. (2013). Manajemen Pemasaran Jasa Berbasis Kompetensi (3 Ed.). Jakarta: Salemba Empat.

Norhermaya, Y. A. (2016). Analisis Pengaruh Kepuasan Pelanggan Terhadap Kepercayaan Dan Loyalitas Pelanggan Untuk Meningkatkan Minat Beli Ulang (Studi Kasus Online Store Lazada.Co.Id). Semarang: Fakultas Ekonomika Dan Bisnis Universitas Diponegoro.

Nurhayati, \& Murti, W. W. (2012). Analisis Faktor-Faktor Yang Mempengaruhi Minat Beli Ulang Masyarakat Terhadap Produk Handphone. Value Added, 8, 47-62.

Saidani, B., \& Arifin, S. (2012). Pengaruh Kualitas Produk Dan Kualitas Layanan Terhadap Kepuasan Konsumen Dan Minat Beli Pada Ranch Market. Riset Manajemen Sains Indonesia (Jrmsi), 3(1), 1-22.

Stanton, W. J. (2007). Manajemen Pemasaran Dan Pemasaran Jasa: Alfabeta

Sugiyono. (2016). Metode Penelitian Kuantitatif Kualitataif Dan Kombinasi (Mixed Methods). Bandung: Alfabeta.

Sunyoto, D. (2013). Dasar-Dasar Manajemen Pemasaran. Yogyakarta: Caps.

Tetanoe, V. R., \& Dharmayanti, D. (2014). Pengaruh Experiential Marketing Terhadap Pembelian Ulang Dengan Kepuasan Pelanggan Sebagai Variable Intervening Di Breadtalk Surabaya Town Square. Manajemen Pemasaran Petra, 2(1), 1-12.

Tjiptono, F. (1999). Strategi Pemsaran. Yogyakarta: Andi.

Tjiptono, F. (2004). Strategi Pemasaran (Ii Ed.). Yogyakarta: Andi.

Tjiptono, F. (2008). Strategi Pemasaran (Iii Ed.). Yogyakarta: Andi.

Tjiptono, F. (2012). Service Manajemen Mewujudkan Layanan Prima (Iii Ed.). Yogyakarta: Andi Offset.

Zahra, A. (2017). Pengaruh Kualitas Pelayanan, Persepsi Harga, Dan Citra Merek Terhadap Kepuasan Pelanggan Pengguna Jasa Transportasi Ojek Online (Studi Pada Pelanggan Gojek Di Kota Yogyakarta). Yogyakarta: Program Studi Manajemen - Jurusan Manajemen Fakultas Ekonomi Universitas Negeri Yogyakarta. 